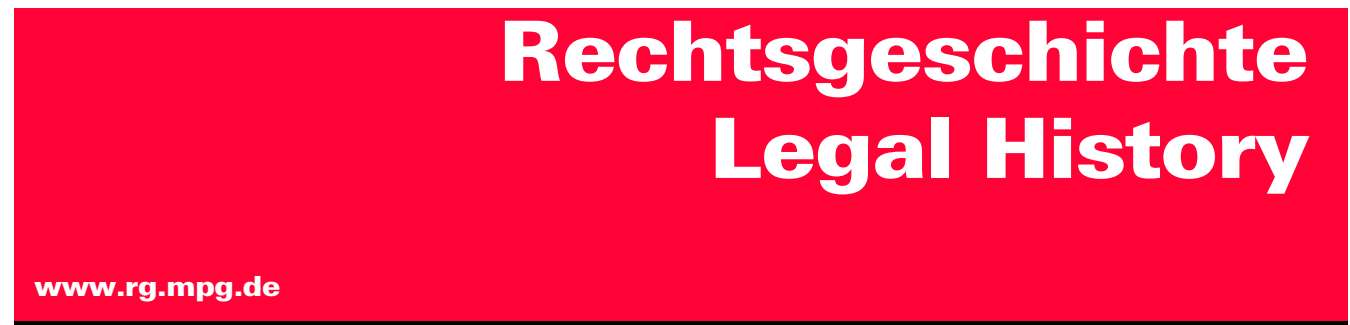

http://www.rg-rechtsgeschichte.de/rg27

Zitiervorschlag: Rechtsgeschichte - Legal History Rg 27 (2019)

$\operatorname{Rg} 272019$

$436-439$

http://dx.doi.org/10.12946/rg27/436-439

\title{
Philipp Siegert*
}

\section{Öffentliches Recht in Frankreich, 1914-1918}

[Public Law in France, 1914-1918]

* Université Paris III - Sorbonne Nouvelle, philipp.siegert@sorbonne-nouvelle.fr

Dieser Beitrag steht unter einer Creative Commons Attribution 4.0 International License 
las organizaciones anti-colonialistas y comunistas se reforzaron mutuamente durante este lapso. De esta forma, el libro contribuye al desarrollo del campo insuficientemente estudiado aún del desarrollo de los regímenes penales transnacionales. ${ }^{5}$

Si fuera posible hacer alguna crítica constructiva a la obra sería que prioriza una lectura superestructural que sólo aisladamente hace referencia a condiciones materiales como condicionantes de los cambios en la vigilancia policial (142, con referencia a la crisis económica de 1929).

Sin perjuicio de ello, es una obra altamente recomendable para entender el pasado y analizar el presente, particularmente en relación a la doble vara o, en palabras del autor, a los vínculos "entre vigilancia policial y racismo global, y a las tensiones entre el objetivo de implementar libertades civiles a nivel doméstico por un lado y los intereses securitarios de los países occidentales por el otro«. Marx ya lo había señalado en el siglos XIX pero hoy más que nunca se debe prestar atención a la expansión policial global en detrimento de los derechos y garantías individuales de los más vulnerables, en el marco del poder irrestricto de potencias occidentales que dicen al mundo: »Haz lo que digo y no lo que hago«.

\section{Philipp Siegert Öffentliches Recht in Frankreich, 1914-1918*}

Im Jahr 2017 sind zwei Sammelbände erschienen, die aus beinahe zeitgleichen Tagungen im November 2015 zur Entwicklung des öffentlichen Rechts in Frankreich 1914-1918 hervorgegangen sind: Der eine ist der von Elina Lemaire (Universität Bourgogne - Franche-Comté) herausgegebene Band zum öffentlichen Recht während des Krieges, der andere der vom Conseil d'État selbst herausgegebene Band zu seiner Funktion und (gestaltenden) Rolle während der Kriegsjahre. Insoweit die Entwicklung des öffentlichen Rechts in Frankreich ohne den Conseil d'État kaum sinnvoll untersucht werden kann und umgekehrt eine Geschichte dieses Conseil kaum unter Auslassung seines Einflusses auf die Rechtsentwicklung geschrieben werden kann, nähern sich beide Bände aus unterschiedlichen (aber auf das öffentliche Recht fokussierten) Perspektiven gewissermaßen einem gemeinsamen
Gegenstand: der Rechtsstaatlichkeit im Krieg und namentlich der Rechtsstaatlichkeit in einer Republik im Krieg.

Lemaires Sammelband bringt die Ergebnisse einer Tagung zu Papier, die Teil des umfangreichen französischen Zyklus Centenaire 14-18 war, welcher in ganz unterschiedlichen Veranstaltungen dem Ausbruch, Verlauf und Ende des Ersten Weltkriegs gewidmet war. Der Band vereint neun wissenschaftliche Beiträge zu Fragen der Entwicklung des öffentlichen Rechts im und durch den Krieg, derjenige des Conseil d'État weitere 14, von Forschern in unterschiedlichen Stadien ihrer Laufbahn (Doktorand bis Emeritus) verfasst. Hier kommen zudem auch etliche Praktiker zu Wort.

In die Themen führen jeweils Romain Rambaud (Droit public) und Martine de Boisdeffre (Conseil d'État) ein, wobei ersterer beim Postulie-
5 Karl Härter, Tina Hannappel, Conrad Tyrichter (coords.), The Transnationalisation of Criminal Law in the Nineteenth and Twentieth Century: Political Crime, Police Cooperation, Security Regimes and Normative Orders, Frankfurt am Main 2019

\footnotetext{
* Elina Lemaire (Hg.), La Grande Guerre et le droit public, Bayonne: Institut Universitaire Varenne 2017, 214 S., ISBN 978-2-37032-115-2; Comité D'Histoire du Conseil D'ÉTAT ET DE LA JURIDICTION administrative (Hg.), Le Conseil d'État et la Grande Guerre. Actes du
}

colloque organisé par le Comité d'histoire du Conseil d'État et de la juridiction administrative, à Paris, les 20 et 21 novembre 2015, Paris: La Documentation française 2017, 283 S., ISBN 978-2-37032-115-2 
ren der zu füllenden Forschungslücke zurückhaltender ist, ohne dass dadurch der wissenschaftliche Ertrag des Bandes geschmälert würde. In der Tat bieten beide Werke lesenswerte Aufsätze, auch und vielleicht gerade für deutschsprachige (Rechts-)Historiker. Rambaud hält zunächst fest, dass Wandlungen weniger in der verfassungsrechtlichen als vielmehr der verwaltungsrechtlichen Sphäre zu beobachten gewesen seien, und in der Tat scheint dieser Befund bei mehreren Beiträgen in beiden Bänden durch (siehe Édouard Bédarrides in Droit public und die Beispiele bei Jean Barthélemy in Conseil d'État). Andererseits muss gleich hervorgehoben werden, dass bspw. die Analysen des Machtgefüges im Staat (Lemaire und Jean-Christophe Videlin in Droit public, Stéphane Audoin-Rouzean in Conseil d'État) sich weitaus grundsätzlicheren und auch politischeren - Fragen widmen als dem Funktionieren des staatlichen Räderwerks auf der behördlichen Ebene. Insgesamt bietet der Band Droit public eine Rundschau, die zwar stets in öffentlich-rechtlichen Fragen verwurzelt bleibt, den Horizont aber in sehr angemessener Weise auch auf nicht-juristische Nachbarfelder ausdehnt. Im Falle des Bandes Conseil d'État ist der erste der drei Hauptteile rundheraus alltags- und kulturgeschichtlich (so bes. die Beiträge von Annie Deperchin zur Trauer und von Antoine Perrier zur Mobilisierung).

Die Beiträge in Lemaires Band können, zugegebenermaßen vereinfachend und schematisierend, in solche mit eher theoretischem oder dogmatischem und solche mit eher analytisch-praktischem Fokus eingeteilt werden. $\mathrm{Zu}$ ersteren wären die Texte von Ludovic Chan-Tung (zur Völkerrechtslehre), Bédarrides (zur Verfassungsrechtslehre) und François Saint-Bonnet (zum Ausnahmezustand) zu rechnen; vielleicht noch der ideengeschichtliche Aufsatz von Xavier Souvignet zu Positivismus, Kosmopolitismus und Internationalismus, welcher zu den besten des Bandes gehört. Die anderen Beiträge betrachten gewissermaßen die normative Kraft des Faktischen, also die Auswirkung der Praxis auf Rechtssätze und -denkfiguren im Bereich der Staatsorganisation (Lemaire, Videlin), der Legalität der Kriegsmittel (Hamza Cherief) oder der finanziellen und wirtschaftlichen Ordnung auch über die Kriegszeit hinaus (Romain Bourrel, Shoji Harada).

Die Beiträge sind fast durchweg fundiert und aufschlussreich, wobei manche trotz des begrenzten Raumes für die Ausführungen sogar ein sehr differenziertes Bild ihres Gegenstandes zu bieten wissen. Alle großen Namen der damaligen Epoche begegnen dem Leser: Adhémar Esmein, Gaston Jèze, Léon Duguit, Maurice Hauriou u.v. m., aber auch weniger bekannte und doch auch einflussreiche Juristen werden nicht übersehen (besonders Bédarrides bietet einen guten Überblick über die Doktrin, dem übrigens derjenige von Bernard Pactau in Conseil d'État in nichts nachsteht; liest man beide gemeinsam - vielleicht noch in Verbindung mit demjenigen von Bernard Stirn in Conseil d'État -, ist man in kurzer Zeit sehr gut orientiert hinsichtlich der öffentlich-rechtlichen Dogmatik bis 1918). Zu der Differenzierung gesellt sich oft ein scharfer Blick für die Begriffe und den Wandel ihres Gehalts während des Krieges, sodass die meisten Beiträger es erfolgreich vermeiden, in die Falle einer »rückwärtsgewandten Prophetie« zu tappen oder zu einfache Pfadabhängigkeiten zu behaupten. In dieser Hinsicht nicht ganz überzeugend bleibt der Beitrag von Chan-Tung, der aus Sicht des Rezensenten zu schnell und vereinfachend heutige Ansichten auf die Jahre 1914/18 rückprojiziert und schematisiert: Der von ihm den französischen Juristen attestierte "nüchterne Patriotismus« (57) wird doch sehr relativiert, wirft man bspw. einen Blick in die Kriegsjahrgänge des Journal du Droit International - die kurzen Ausführungen in Bédarrides Aufsatz (112-114) sind da ausgewogener. Auch die Behauptung, die französische Rechtslehre habe schon vor dem Krieg durchweg einer »relativen Souveränität« der Staaten im internationalen Recht (im Gegensatz zur Selbstbindungslehre) das Wort geredet (71), kann schon anhand des Traité de droit international public des prominenten Völkerrechtlers Alexandre Mérignhac (1905) widerlegt werden, für den gerade die Selbstbindung die Basis allen Völkerrechts war.

Gelungener ist insbesondere der Aufsatz von Souvignet, der übrigens nicht nur für Rechtshistoriker von Interesse sein kann. Auf 18 Seiten (Droit public, 79-97) bietet er einen sehr lesenswerten tour d'horizon zu verschiedenen Denkfiguren »des Internationalen«. Sein Ausgangspunkt ist interessanterweise Carl Schmitts »konkretes Ordnungsdenken« (80-82) sowie der Befund, dass seit den Pariser Vorortkonferenzen von 1919/20 nicht mehr Europa die Welt, sondern die Welt Europa ordnet (89). Der Erste Weltkrieg wird schließlich als ein Element in der Entwicklung vom Liberalismus des 19. Jahrhunderts hin zu einer Art kognitiven Dissonanz (»strukturelle Schizophrenie«, 93) zwi- 
schen kosmopolitischer Denkweise und internationaler Rechtsordnung gewertet - gewissermaßen Weltbürger- und Weltrepublikidee einerseits, intergouvernementale und nationalstaatsbezogene reale Ordnung andererseits. In der deutschsprachigen Historiographie könnte man hier hervorragend z. B. an Heinz Gollwitzers Geschichte des weltpolitischen Denkens anknüpfen.

Der Beitrag der Herausgeberin Lemaire befasst sich mit der Frage der Ermächtigungsgesetzgebung in Frankreich, speziell mit dem (am Parlament gescheiterten) Projekt der Regierung von Aristide Briand zur Jahreswende 1916/17, welches in ihrer Einschätzung das erste Projekt einer »allgemeinen Ermächtigung« in Frankreich (129) war. Wie die meisten Beiträge geht auch Lemaire in ihrer Untersuchung trotz begrenzter Seitenzahl minutiös vor und kontextualisiert ihren Gegenstand historisch und politisch sehr gut. Ihr Aufsatz bietet einen spannenden Blick in das innere Geschehen des Gesetzgebungsprozesses im republikanischen Frankreich nach dem Wiedererstarken der parlamentarischen Kontrolle (bes. 129-139). Hier bietet sich eine anschließende Lektüre von Olivier Cartons Beitrag in Conseil d'État an, welcher einen guten Einblick in den Umgang des Conseil d'État mit »dem Gesetz« in seiner konsultativen Rolle bietet.

Ein thematisch scheinbar etwas entfernterer Beitrag in Droit public ist derjenige von Bourrel zu Finanz- und Steuerrecht. Auch ihm gelingt aber die Verbindung durchaus spezieller und technischer Erklärungen mit einer Einordnung in die größeren Entwicklungslinien der Staatlichkeit an sich. Zunächst einmal ist interessant, dass die steuerpolitische »Ideologie" der Republik dahin ging, Steuern nur zur Finanzierung »normaler« Staatsaktivität zu verwenden (170), nicht hingegen zur Kriegsfinanzierung: Diese wurde durch Verschuldung des Staates teils im Inland, dann aber mehr und mehr im Ausland getätigt: Hatte Frankreich 1913 eine Gesamtverschuldung von 33 Mrd. Franken, so betrug allein die Auslandsverschuldung 1918 über 43 Mrd. Franken. Hinsichtlich der Auswirkung des Ersten Weltkrieges beobachtet der Autor drei »institutionelle und materielle Veränderungen «(177-179): erstens eine Verschiebung von der indirekten zur direkten Besteuerung (namentlich mit der Einkommenssteuer), welche er aber auf Zahlen gestützt als eine graduelle, keine fundamentale Veränderung bewertet. (Interessanterweise stellt sich der gegenteilige Eindruck hin- sichtlich der Zahl der Streitverfahren in diesem Feld ein: knapp 900 im Jahr 1914, aber fast 6.000 im Jahr 1918; Catherine Lecomte in Conseil d'État, 183.) Wichtiger war ihm zufolge, zweitens, die Einführung der Gewinnsteuer 1916, welche zwar während des Krieges finanziell kaum ins Gewicht gefallen sei, aber hernach »explodierende Einnahmen" (178) geboten habe und jedenfalls eine Neuerung grundsätzlicher Art gewesen sei. Drittens schließlich habe der Krieg - und die beschleunigte Entwicklung hin zum Sozialstaat (in dieser Hinsicht verweist Rambaud auf eine »explodierende Verwaltung « im 20. Jahrhundert: Droit public, 13) - zu einer erheblichen Verschiebung im institutionellen Gefüge des Staates geführt, da dem Finanzministerium nach 1919 ein ganz anderes Gewicht zugekommen sei als vor 1914.

Beide Bände bieten eine lehrreiche Lektüre, insbesondere, wenn man sie gemeinsam liest und manche Beiträge zueinander in Verbindung setzt. Die »kombinierte« Lektüre bietet zudem den Vorteil, dass gerade durch einen Teil der Aufsätze in Conseil d'État das Bild, das der Leser von der Rechtsentwicklung 1914-1918 erhält, gewissermaßen in der erlebten Realität geerdet wird. Diese war natürlich von direkter oder mindestens indirekter Gewalterfahrung geprägt: Auch die Männer des Conseil d'État blieben nicht von der Mobilisierung oder gar dem Kriegstod gefeit, wie Terry Olson mit Pathos (später von Deperchin gelungen relativiert) und Marc Bouvet mit nüchternen Zahlen darlegen - letzterer übrigens gleich in zwei Beiträgen (67-80 und 107-122), wobei die vielen Überschneidungen es wohl auch hätten rechtfertigen können, sie zu einem einzigen zu verbinden. Insgesamt bietet der Band Conseil d'État schon wegen seiner weiteren Fragestellung einen Blick hinter die Kulissen, der für das Verständnis der Rechtsentwicklung, die in Droit public dargestellt wird, von großem Gewinn ist. Im Übrigen geht bei den Betrachtungen in Conseil d'État trotz der Schwere des Themas auch der Humor nicht verloren, wenngleich er anekdotisch bleibt - wie bei der in Conseil d'État behandelten Frage der Anbringung grüner Warnaufkleber auf bestimmte Schönheitsprodukte: „Das wird die Verkaufszahlen [der Schönheitssalons] mindern.«-»Ich gehe nicht in Schönheitssalons.« - »Ihr Verlust.« (166-167)

Summa summarum bieten beide Bücher lesenswerte Einblicke in mehrere Bereiche, die mit dem öffentlichen Recht, mit dem Staatsaufbau der Dritten Republik oder mit der Rechtsstaatlichkeit in 
ihrer republikanischen Form eng verbunden sind, und gerade dem deutschen Publikum eröffnen sie eine Lesart des Ersten Weltkriegs, die wertvolle Orientierungspunkte für die rechts-, aber auch politik- und sogar kulturhistorische Auseinandersetzung mit 1914-1918 liefert.

\section{Anna Clara Lehmann Martins A »diabolical Constitution« in Mexico*}

»[A] diabolical Constitution, even more, the worst of all preceding vexatious laws. «These words were uttered by Cardinal De Lai during the session of 9 June 1918 of the Congregation for Extraordinary Ecclesiastical Affairs (AAEESS). He was referring to the Mexican Constitution of 1917, in particular to the norms that established severe limitations to the autonomy of the Catholic Church in the country. Mexican bishops, many of whom were forced into exile in the United States, Cuba or Europe during the 1910s, soon formed a transnational network of communication in order to protect each other and react to the anticlerical measures of Venustiano Carranza's government. The traces of this network - which include reports and dubia of the Mexican clergy, diplomatic correspondence, press excerpts, letters and decisions of Roman authorities - are explored by Professor Carmen-José Alejos Grau in her recent book. Una historia olvidada e inolvidable. Carranza, Constitución e Iglesia Católica en México (1914-1919) focuses on the perspective of ecclesiastics within the scenario of tension in which the Constitution of 1917 was conceived and enforced. This perspective is still underresearched in the historiography dedicated to the Mexican Revolution, but crucial to understanding the turbulent dynamics of Church and State relations in the country. Alejos Grau's narrative is based on unpublished sources from the Vatican
Secret Archives and the Historical Archives of the Secretariat of State of the Holy See.

The book is divided into five chapters and one annex. Chapter 1 provides important contextual information. It outlines the stormy international landscape and the state of the Mexican Revolution until the rise of Carranza. Alejos Grau illustrates the situation of the Catholic Church in Mexico with a report written by the archbishops of $\mathrm{Mi}$ choacán and Linares in 1914, in which they refute the revolutionary groups' accusations that the Mexican episcopate supported Porfirio Díaz and conspired against Francisco Madero. These accusations, along with the violent anticlericalism of agents in positions of power, led to the exile of a large number of bishops, clergymen and members of religious orders. This chapter also shows how, in the absence of a Mexican representative, the Apostolic Delegate to the United States, Monsignor Giovanni Bonzano, came to play the role of mediator between the exiled bishops, diplomatic authorities and the Holy See.

The core of the book is Chapter 2, in which the reactions of the episcopate in the face of the elaboration and promulgation of the Mexican Constitution of 1917 are discussed. More radical in religious matters than its 1857 predecessor, the new constitution prescribed lay education for all public and private institutions; it denied legal

\footnotetext{
Carmen-José Alejos Grau, Una historia olvidada e inolvidable. Carranza, Constitución e Iglesia Católica en México (1914-1919), Mexico: Universidad Nacional Autónoma de México 2018, 609 p., ISBN 978-607-30-1135-8
} 